\title{
Hetarenocoumarins based on 7-hydroxy-3-(benzothiazol-2-yl)coumarin
}

\author{
Tetyana Shokol, Anastasiya Suprun, Victoriia Moskvina*, Volodymyr Khilya \\ Department of Chemistry, Taras Shevchenko National University of Kyiv, Volodymyrska Street, \\ 64/13, Kyiv 01601, Ukraine \\ v.moskvina@gmail.com
}

Keywords: 7-hydroxy-3-benzothiazolylcoumarin, aminomethylation, formylation, cyclization, hetarenocoumarins.

The syntheses of angular hetarenocoumarins, namely chromeno[8,7-e][1,3]oxazin-2-ones and furo[2,3- $h]$ chromen-2-one, have been accomplished starting from 7-hydroxy-3-(benzothiazol-2-yl)coumarin using aminomethylation and formylation reactions.

\section{Introduction}

\section{Coumarins appear} naturally in many plants and find wide use in medicine due to their diverse pharmacological activities [1, 2]. They possess excellent photophysical properties such as high quantum yield, strong fluorescence, and high photostability, and therefore are used as dyes for biosensitization and biomarking [3]. 7Hydroxycoumarin derivatives proved to be popular fluorescent dyes. Heterocyclic substituents in position 3 cause a bathochromic shift of their maximum absorption, which significantly improves the photophysical properties of coumarins.

\section{3-Benzothiazolylcoumarins}

are actively used as fluorescent probes for rapid detection of $\mathrm{H}_{2} \mathrm{~S}$ [4], benzenethiols [5], biothiols [6], selenocysteine [7], catecholamine [8], $\mathrm{Cu}^{2+}$ [9], for sequential recognition of $\mathrm{Ni}^{2+}$ and $\mathrm{CN}^{-}$[10], hydrazine
[11], superoxides [12], palladium [13], and hydrogen peroxide [14]. Many probes were synthesized based on 7-hydroxy-3benzothiazolylcoumarin, which itself can serve as a laser dye [15].

In addition, the use of 3benzothiazolylcoumarin derivatives as potential antitumor agents [16] and MEK1 inhibitors has been suggested [17]. 7Hydroxy-3-benzothiazolylcoumarin was synthesized by the Knoevenagel reaction via interaction of 2,4-dihydroxybenzaldehyde with (benzothiazol-2-yl)acetonitrile in ethanol $[7,17,18]$ or propanol-2 [19] using piperidine [17-19] or $4 \% \mathrm{NaOH}$ [3] as a catalyst, followed by hydrolysis with sulfuric [18] or hydrochloric acid $[3,7,17,19]$ or with ethyl 2-benzothiazolyl acetate in pyridine in the presence of aniline as a catalyst [20]. In the second approach, 7-hydroxy-3benzothiazolylcoumarin was synthesized 
from 7-hydroxy-3-cyanocoumarin and 2aminothiophenol under microwave irradiation in acetic acid or ethanol with a catalytic amount of the HPMo $\left(\mathrm{H}_{3} \mathrm{PMo}_{12} \mathrm{O}_{3}\right)$ [21]. Alkylation and acylation of the hydroxyl group [3, 18], aminomethylation [18, 22, 23], and formylation $[23,24]$ at position 8 and cyanation at position 4 [17] of 7-hydroxy-3(benzothiazol-2-yl)coumarin were previously studied.

\section{Experimental part}

The reaction progress and identity of obtained compounds were monitored by TLC on Silufol UV-254 plates using $\mathrm{CHCl}_{3}-\mathrm{MeOH}$ (9:1) system. Melting points were determined using a Kofler-type Leica Galen III micro hot stage microscope. NMR spectra were recorded on Varian Mercury 400 spectrometer (spectrometer frequency for ${ }^{1} \mathrm{H}$ : $400 \mathrm{MHz}$ ) using a DMSO residual solvent signal as an internal standard; chemical shifts ( $\delta)$ are given in ppm. Elemental analyses for $\mathrm{C}, \mathrm{H}$, and $\mathrm{N}$ were performed using Vario micro cube (Elementar Analysen-systeme $\mathrm{GmbH})$, their results were found to be in good agreement $(0.2 \%)$ with the calculated values. Mass spectra were recorded on an Agilent 1100 LC / MSD with chemical ionization (SI). 3-(1,3-Benzothiazol-2-yl)-8dimethylamino-methyl-7-hydroxy-2H-2chromenone $\mathbf{2}$ was synthesized following a published protocol [18].
3-(1,3-Benzothiazol-2-yl)-7-

hydroxy-2H-2-chromenone 1. 2 Drops of piperidine were added to a solution of 2,4dihydroxybenzaldehyde (1.38 g, $10 \mathrm{mmol})$ and (benzothiazole-2)-yl)acetonitrile (1.74 g, $10 \mathrm{mmol})$ in $\mathrm{EtOH}(30 \mathrm{~mL})$ and kept for 2 days at room temperature. Then the precipitate was filtered off and refluxed for 5 $\mathrm{h}$ in $50 \mathrm{~mL}$ of acetic acid. The mixture was cooled and the precipitate was filtered off. Yield 2.6 g, 88 \%. Yellow solid, $\mathrm{C}_{16} \mathrm{H}_{9} \mathrm{NO}_{3} \mathrm{~S}$, $\mathrm{mp} 308^{\circ} \mathrm{C}(\mathrm{AcOH})$ (lit. [18] $295^{\circ} \mathrm{C}$, [19] $\left.305^{\circ} \mathrm{C}\right) . \quad{ }^{1} \mathrm{H} \mathrm{NMR}$ spectrum $\quad(400 \mathrm{MHz}$, DMSO- $\left.d_{6}-\mathrm{CCl}_{4}\right), \delta, \operatorname{ppm}(J, \mathrm{~Hz}): 6.79(1 \mathrm{H}, \mathrm{d}$, $J=2.0, \mathrm{H}-8), 6.66\left(1 \mathrm{H}, \mathrm{dd}, J_{6,5}=8.8, J_{6,8}=2.0\right.$, H-6), 7.38 (1H, t, $\left.J=8.0, \mathrm{H}-6^{\prime}\right), 7.48$ (1H, t, $\left.J=8.0, \mathrm{H}-5^{\prime}\right), 7.77(1 \mathrm{H}, \mathrm{d}, J=8.8, \mathrm{H}-5), 7.96$ $\left(1 \mathrm{H}, \mathrm{d}, J=8.0, \mathrm{H}-4^{\prime}\right), 8.02(1 \mathrm{H}, \mathrm{d}, J=8.0, \mathrm{H}-$ 7'), 9.09 (1H, s, H-4), 10.84 (1H, s, OH).

General procedure for the preparation of 3-(1,3-benzothiazol-2-yl)-9-R9,10-dihydro-2H,8H-chromeno[8,7-

e][1,3]oxazin-2-ones 3a-c. The corresponding benzylamine $(0.2 \mathrm{~mL}, 2 \mathrm{mmol})$ and $37 \%$ formalin $(4 \mathrm{~mL})$ were added to 3-(1,3benzothiazol-2-yl)-7-hydroxy-2H-2-

chromenone 1 (0.32 g, $1 \mathrm{mmol})$ in $10 \mathrm{~mL}$ of dioxane and refluxed for $3 \mathrm{~h}$ (TLC control). The solution was cooled and the resulting precipitate was filtered off and washed with dioxane. 
3-(1,3-Benzothiazol-2-yl)-9-benzyl9,10-dihydro-2H,8H-chromeno[8,7-e][1,3]oxazin-2-one 3a. Yield $0.26 \mathrm{~g}, 62 \%$. Yellow solid, $\quad \mathrm{C}_{25} \mathrm{H}_{18} \mathrm{~N}_{2} \mathrm{O}_{3} \mathrm{~S}, \quad \mathrm{mp} \quad 196-197^{\circ} \mathrm{C}$ (dioxane). ${ }^{1} \mathrm{H}$ NMR spectrum $(400 \mathrm{MHz}$, DMSO- $\left.d_{6}-\mathrm{CCl}_{4}\right), \delta, \operatorname{ppm}(J, \mathrm{~Hz}): 3.90(2 \mathrm{H}$, $\left.\mathrm{s}, \mathrm{PhC}_{2}\right), 4.16\left(2 \mathrm{H}, \mathrm{s}, 10-\mathrm{CH}_{2}\right), 4.98(2 \mathrm{H}$, s, 8- $\left.\mathrm{CH}_{2}\right), 6.84(1 \mathrm{H}, \mathrm{d}, J=8.8, \mathrm{H}-6), 7.26-$ 7.39 (6H, m, H-6', Ph), 7.47 (1H, t, $J=8.0$, H-5'), $7.73(1 \mathrm{H}, \mathrm{d}, J=8.8, \mathrm{H}-5), 7.96(1 \mathrm{H}, \mathrm{d}$, $\left.J=8.4, \mathrm{H}-4^{\prime}\right), 7.99$ (1H, d, $\left.J=8.4, \mathrm{H}^{-} 7^{\prime}\right), 9.08$ (1H, s, H-4). MS (m/z, CI): $415\left[\mathrm{MH}^{+}-12\right]$.

3-(1,3-Benzothiazol-2-yl)-9-(4-

methoxybenzyl)-9, 10-dihydro-2H,8H-

chromeno[8,7-e][1,3]oxazin-2-one 3b. Yield 0.34 g, $74 \%$. Yellow solid, $\mathrm{C}_{26} \mathrm{H}_{20} \mathrm{~N}_{2} \mathrm{O}_{4} \mathrm{~S}$, mp $203-204^{\circ} \mathrm{C}$ (dioxane). ${ }^{1} \mathrm{H}$ NMR spectrum (400 MHz, DMSO- $\left.d_{6}-\mathrm{CCl}_{4}\right), \delta$, ppm $(J, \mathrm{~Hz})$ : $3.77\left(3 \mathrm{H}, \mathrm{s}, \mathrm{CH}_{3} \mathrm{O}\right), 3.81\left(2 \mathrm{H}, \mathrm{s}, \mathrm{PhCH}_{2}\right)$, $4.13\left(2 \mathrm{H}, \mathrm{s}, 10-\mathrm{CH}_{2}\right), 4.97\left(2 \mathrm{H}, \mathrm{s}, 8-\mathrm{CH}_{2}\right)$, $6.85\left(3 \mathrm{H}, \mathrm{d}, J=8.4, \mathrm{H}-6, \mathrm{H}-3^{\prime \prime}, 5^{\prime \prime}\right), 7.23$ (2H, d, $\left.J=8.0, \mathrm{H}-2^{\prime \prime}, 6^{\prime \prime}\right), 7.39$ (1H, t, $J=8.0$, H-6'), 7.49 (1H, t, $\left.J=8.0, \mathrm{H}-5^{\prime}\right), 7.77(1 \mathrm{H}, \mathrm{d}$, $J=8.4, \mathrm{H}-5), 7.97$ (1H, d, $\left.J=8.0, \mathrm{H}-4^{\prime}\right), 8.01$ (1H, d, $\left.J=8.0, \mathrm{H}^{-} 7^{\prime}\right), 9.11$ (1H, s, H-4). MS $(\mathrm{m} / \mathrm{z}, \mathrm{CI}): 444.9\left[\mathrm{MH}^{+}-12\right]$.

3-(1,3-Benzothiazol-2-yl)-9-(1-

phenylethyl)-9, 10-dihydro-2H,8H-

chromeno[8,7-e][1,3]oxazin-2-one 3c. Yield $0.35 \mathrm{~g}, 79 \%$. Yellow solid, $\mathrm{C}_{26} \mathrm{H}_{20} \mathrm{~N}_{2} \mathrm{O}_{3} \mathrm{~S}$, mp $104-105^{\circ} \mathrm{C}$ (dioxane). ${ }^{1} \mathrm{H}$ NMR spectrum (400 MHz, DMSO- $\left.d_{6}-\mathrm{CCl}_{4}\right), \delta$, ppm $(J, \mathrm{~Hz})$ : $1.45\left(3 \mathrm{H}, \mathrm{d}, J=7.2, \mathrm{CH}_{3}\right), 3.91(1 \mathrm{H}, \mathrm{k}, J=7.2$, $\left.\mathrm{C} \mathrm{HCH}_{3}\right), 3.97\left(1 \mathrm{H}, \mathrm{d}, J=17.2,10-\mathrm{CH}_{\alpha}\right), 4.26$ $\left(1 \mathrm{H}, \mathrm{d}, J=17.2, \quad 10-\mathrm{CH}_{\beta}\right), 4.96(1 \mathrm{H}, \mathrm{d}$, $\left.J=10.4,8-\mathrm{CH}_{\alpha}\right), 5.20$ (1H, d, $J=10.4,8$ $\left.\mathrm{CH}_{\beta}\right), 6.83(1 \mathrm{H}, \mathrm{d}, J=8.8, \mathrm{H}-6), 7.26-7.33$ (5H, m, Ph), 7.38 (1H, t, $\left.J=8.0, \mathrm{H}-6^{\prime}\right), 7.49$ $\left(1 \mathrm{H}, \mathrm{t}, J=8.0, \mathrm{H}-5^{\prime}\right), 7.74(1 \mathrm{H}, \mathrm{d}, J=8.8, \mathrm{H}-$ 5), 7.97 (1H, d, J=8.0, H-4'), 8.01 (1H, d, $J=$ 8.0, H-7'), 9.01 (1H, s, H-4). MS ( $m / z, \mathrm{CI})$ : $429\left[\mathrm{MH}^{+}-12\right]$.

General procedure for the preparation of 3-(1,3-benzothiazol-2-yl)-7hydroxy-2-oxo-2H-8-chromenylmethyl-

(R)ammonium chlorides $\mathbf{4 a}$-c. $\mathrm{HCl}(0.1 \mathrm{~mL})$ was added to the solution of 3-(1,3benzothiazol-2-yl)-9-R-9,10-dihydro2H,8H-chromeno[8,7-e][1,3] oxazin-2-one 3a-c $(0.3 \mathrm{mmol})$ in dioxane $(3 \mathrm{~mL})$ and the reaction mixture was refluxed for $1 \mathrm{~h}$, then it was cooled and the resulted precipitate was filtered off and washed with dioxane.

$$
\text { 3-(1,3-Benzothiazol-2-yl)-7- }
$$

hydroxy-2-oxo-2H-8-chromenylmethyl(benzyl)ammonium chloride 4a. Yield 0.09 g, $67 \%$. Yellow solid, $\mathrm{C}_{24} \mathrm{H}_{19} \mathrm{ClN}_{2} \mathrm{O}_{3} \mathrm{~S}$, mp 268-269 ${ }^{\circ} \mathrm{C}$ (dioxane). ${ }^{1} \mathrm{H}$ NMR spectrum (400 MHz, DMSO- $\left.d_{6}-\mathrm{CCl}_{4}\right), \delta$, ppm $(J, \mathrm{~Hz})$ : $4.20\left(2 \mathrm{H}, \mathrm{s}, \mathrm{PhCH}_{2}\right), 4.24\left(2 \mathrm{H}, \mathrm{s}, \mathrm{CH}_{2}\right), 7.23$ 
$(1 \mathrm{H}, \mathrm{d}, J=8.4, \mathrm{H}-6), 7.36-7.39(4 \mathrm{H}, \mathrm{m}, \mathrm{H}-$ $\left.6^{\prime}, 3^{\prime \prime}, 4^{\prime \prime}, 5^{\prime \prime}\right), 7.48\left(1 \mathrm{H}, \mathrm{t}, J=7.6, \mathrm{H}-5^{\prime}\right), 7.62$ (2H, d, $\left.J=7.2, \mathrm{H}-2^{\prime \prime}, 6^{\prime \prime}\right), 7.85(1 \mathrm{H}, \mathrm{d}, J=8.4$, H-5), $7.96\left(1 \mathrm{H}, \mathrm{d}, J=7.6, \mathrm{H}-4^{\prime}\right), 8.02(1 \mathrm{H}, \mathrm{d}$, $\left.J=8.4, \mathrm{H}-7^{\prime}\right), 9.11$ (1H, s, H-4), 9.63 (2H, s, $\left.\mathrm{NH}_{2}\right), 12.11$ (1H, s, OH). MS (m/z, CI): 415 $\left[\mathrm{MH}^{+}-36.5\right]$.

\section{3-(1,3-Benzothiazol-2-yl)-7-}

hydroxy-2-oxo-2H-8-chromenylmethyl(4methoxybenzyl)ammonium chloride $\mathbf{4 b}$. Yield $\quad 0.11 \mathrm{~g}, \quad 78 \%$. Yellow solid, $\mathrm{C}_{25} \mathrm{H}_{21} \mathrm{ClN}_{2} \mathrm{O}_{4} \mathrm{~S}$, mp $263-264^{\circ} \mathrm{C}$ (dioxane). ${ }^{1} \mathrm{H}$ NMR spectrum $\left(400 \mathrm{MHz}\right.$, DMSO- $d_{6^{-}}$ $\left.\mathrm{CCl}_{4}\right), \delta, \operatorname{ppm}(J, \mathrm{~Hz}): 3.76\left(3 \mathrm{H}, \mathrm{s}, \mathrm{CH}_{3} \mathrm{O}\right)$, $4.13\left(2 \mathrm{H}, \mathrm{s}, \mathrm{PhCH}_{2}\right), 4.22\left(2 \mathrm{H}, \mathrm{s}, \mathrm{CH}_{2}\right), 6.89$ $\left(2 \mathrm{H}, \mathrm{d}, J=8.4, \mathrm{H}-3^{\prime \prime}, 5^{\prime \prime}\right), 7.22(1 \mathrm{H}, \mathrm{d}, J=8.8$, H-6), 7.39 (1H, t, $\left.J=8.0, \mathrm{H}-6^{\prime}\right), 7.47-7.52$ $\left(3 \mathrm{H}, \mathrm{m}, \mathrm{H}-5^{\prime}, 2^{\prime \prime}, 6^{\prime \prime}\right), 7.86(1 \mathrm{H}, \mathrm{d}, J=8.8, \mathrm{H}-$ 5), 7.97 (1H, d, $\left.J=8.0, \mathrm{H}-4^{\prime}\right), 8.03(1 \mathrm{H}, \mathrm{d}, J=$ 8.0, H-7'), 9.12 (1H, s, H-4), 9.46 (2H, s, $\left.\mathrm{NH}_{2}\right), 12.08$ (2H, s, OH). MS (m/z, CI): 445 $\left[\mathrm{M}^{+}-36.5\right]$.

\section{3-(1,3-Benzothiazol-2-yl)-7-}

hydroxy-2-oxo-2H-8-chromenylmethyl(1phenylethyl)ammonium chloride 4c. Yield 0.12 g, 86 \%. Yellow solid, $\mathrm{C}_{25} \mathrm{H}_{21} \mathrm{ClN}_{2} \mathrm{O}_{3} \mathrm{~S}$, mp 222-223 ${ }^{\circ} \mathrm{C}$ (dioxane). ${ }^{1} \mathrm{H}$ NMR spectrum (400 MHz, DMSO- $\left.d_{6}-\mathrm{CCl}_{4}\right), \delta, \operatorname{ppm}(J, \mathrm{~Hz})$ : $1.68\left(3 \mathrm{H}, \mathrm{d}, J=6.0, \mathrm{CH}_{3}\right), 3.96(1 \mathrm{H}$, br s, $\mathrm{PhC} \underline{\mathrm{H}}), 4.11\left(2 \mathrm{H}\right.$, br s, $\left.\mathrm{CH}_{2}\right), 7.19(1 \mathrm{H}, \mathrm{d}, J=$
8, H-6), 7.33-7.39 (4H, m, H-6', 3", $\left.4^{\prime \prime}, 5^{\prime \prime}\right)$, $7.46\left(1 \mathrm{H}, \mathrm{t}, J=8.0, \mathrm{H}-5^{\prime}\right), 7.63(2 \mathrm{H}, \mathrm{d}, J=$ 7.2, H-2",6"), 7.79 (1H, d, $J=8, \mathrm{H}-5), 7.94$ $\left(1 \mathrm{H}, \mathrm{d}, J=8.0, \mathrm{H}-4^{\prime}\right), 8.02(1 \mathrm{H}, \mathrm{d}, J=8.0, \mathrm{H}-$ 7'), 9.06 (1H, s, H-4), 9.36 (1H, s, NH), 9.89 $(1 \mathrm{H}, \mathrm{s}, \mathrm{NH}), 1,2.03(1 \mathrm{H}, \mathrm{s}, \mathrm{OH}) . \mathrm{MS}(\mathrm{m} / z$, CI): $429\left[\mathrm{MH}^{+}-36.5\right]$.

General procedure for the preparation of 3-(1,3-benzothiazol-2-yl)-8R-aminomethyl-7-hydroxy-2H-2-

chromenones 5a-c. A mixture of 3-(1,3benzothiazol-2-yl)-8-dimethylaminomethyl7-hydroxy-2H-2-chromenone 3 (0.35 g, $1 \mathrm{mmol}$ ) and substituted benzylamine ( $2 \mathrm{mmol}$ ) was refluxed in $3 \mathrm{~mL}$ of dioxane for $2 \mathrm{~h}$ (TLC control). The solution was cooled and the resulting precipitate was filtered off and washed with dioxane.

3-(1,3-Benzothiazol-2-yl)-8-benzylaminomethyl-7-hydroxy-2H-2-chromenone 5a. Yield $0.20 \mathrm{~g}, 49 \%$. Yellow solid, $\mathrm{C}_{24} \mathrm{H}_{18} \mathrm{~N}_{2} \mathrm{O}_{3} \mathrm{~S}$, mp $242-243^{\circ} \mathrm{C}$ (dioxane). ${ }^{1} \mathrm{H}$ NMR spectrum $\left(400 \mathrm{MHz}\right.$, DMSO- $d_{6^{-}}$ $\left.\mathrm{CCl}_{4}\right), \delta, \operatorname{ppm}(J, \mathrm{~Hz}): 3.92\left(2 \mathrm{H}, \mathrm{s}, \mathrm{PhCH}_{2}\right)$, $4.21\left(2 \mathrm{H}, \mathrm{s}, \mathrm{NHC}_{2}\right), 6.61(1 \mathrm{H}, \mathrm{d}, J=8.4$, H-6), 7.29-7.46 (7H, m, H-5',6', Ph), 7.56 $(1 \mathrm{H}, \mathrm{d}, J=8.4, \mathrm{H}-5), 7.90(1 \mathrm{H}, \mathrm{d}, J=8.0, \mathrm{H}-$ 4'), $7.96\left(1 \mathrm{H}, \mathrm{d}, J=8.0, \mathrm{H}-7^{\prime}\right), 8.94(1 \mathrm{H}, \mathrm{s}$, $\mathrm{H}-4), \mathrm{OH}$ and $\mathrm{NH}$ exchanged with $\mathrm{D}_{2} \mathrm{O}$ ). $\operatorname{MS}(m / z, C I): 415[\mathrm{MH}]^{+}$. 


\section{3-(1,3-Benzothiazol-2-yl)-7-}

hydroxy-8-(4-methoxybenzylaminomethyl)-

2H-2-chromenone 5b. Yield $0.22 \mathrm{~g}, 50 \%$.

Yellow solid, $\mathrm{C}_{25} \mathrm{H}_{20} \mathrm{~N}_{2} \mathrm{O}_{4} \mathrm{~S}$, mp $257-258^{\circ} \mathrm{C}$

(dioxane). ${ }^{1} \mathrm{H}$ NMR spectrum $(400 \mathrm{MHz}$,

DMSO- $\left.d_{6}-\mathrm{CCl}_{4}\right), \delta, \operatorname{ppm}(J, \mathrm{~Hz}): 3.77(3 \mathrm{H}$,

s, $\left.\mathrm{CH}_{3} \mathrm{O}\right), 3.91\left(2 \mathrm{H}, \mathrm{s}, \mathrm{PhCH}_{2}\right), 4.17(2 \mathrm{H}, \mathrm{s}$,

$\left.\mathrm{NHCH}_{2}\right), 6.54$ (1H, d, $\left.J=8.4, \mathrm{H}-6\right), 6.88$

$\left(2 \mathrm{H}, \mathrm{d}, J=8.4, \mathrm{H}-3^{\prime \prime}, 5^{\prime \prime}\right), 7.29-7.35$ (3H, m,

H-6 $\left.6^{\prime}, 2^{\prime \prime}, 6^{\prime \prime}\right), 7.43$ (1H, t, $\left.J=8.0, \mathrm{H}-5^{\prime}\right), 7.53$

$(1 \mathrm{H}, \mathrm{d}, J=8.4, \mathrm{H}-5), 7.89$ (1H, d, $J=8.0, \mathrm{H}-$

4'), $7.96\left(1 \mathrm{H}, \mathrm{d}, J=8.0, \mathrm{H}-7^{\prime}\right), 8.90(1 \mathrm{H}, \mathrm{s}$,

$\mathrm{H}-4), \mathrm{OH}$ and $\mathrm{NH}$ exchanged with $\mathrm{D}_{2} \mathrm{O}$ ).

$\operatorname{MS}(\mathrm{m} / z, \mathrm{CI}): 445[\mathrm{MH}]^{+}$.

\section{3-(1,3-Benzothiazol-2-yl)-7-}

hydroxy-8-(1-phenylethylaminomethyl)-2H-

2-chromenone 5c. Yield $0.23 \mathrm{~g}, 54 \%$.

Yellow solid, $\mathrm{C}_{25} \mathrm{H}_{20} \mathrm{~N}_{2} \mathrm{O}_{3} \mathrm{~S}$, mp $189-190^{\circ} \mathrm{C}$

(dioxane). ${ }^{1} \mathrm{H} \mathrm{NMR}$ spectrum $(400 \mathrm{MHz}$,

DMSO- $\left.d_{6}-\mathrm{CCl}_{4}\right), \delta, \operatorname{ppm}(J, \mathrm{~Hz}): 1,48(3 \mathrm{H}$,

d, $\left.J=6.0, \mathrm{CH}_{3}\right), 3.93-4.07\left(3 \mathrm{H}, \mathrm{m}, \mathrm{CH}_{3} \mathrm{C} \underline{\mathrm{H}}\right.$,

$\left.\mathrm{NHC}_{2}\right), 6.61(1 \mathrm{H}, \mathrm{d}, J=8.4, \mathrm{H}-6), 7.6$ -

7.46 (7H, m, H-5', 6', Ph), 7.57 (1H, d, $J=$

8.4, H-5), 7.91 (1H, d, J=8.0, H-4'), 7.97

(1H, d, $\left.J=8.0, \mathrm{H}^{-} 7^{\prime}\right), 8.94$ (1H, s, H-4), OH

and $\mathrm{NH}$ exchanged with $\left.\mathrm{D}_{2} \mathrm{O}\right)$. MS $(\mathrm{m} / z$,

CI): $429[\mathrm{MH}]^{+}$.

$$
\text { 3-(1,3-Benzothiazol-2-yl)-7- }
$$

hydroxy-2-oxo-2H-8-chromenecarbaldehyde 6.
Method A. A solution of 3-(1,3benzothiazol-2-yl)-7-hydroxy-2H-2-

chromenone 1 (1.48 g, $5 \mathrm{mmol})$ and of hexamethylenetetramine $(7 \mathrm{~g}, 50 \mathrm{mmol})$ in $20 \mathrm{~mL}$ of $\mathrm{AcOH}$ was heated on a water bath for $6 \mathrm{~h}$. The hot solution was poured into a hot mixture of $\mathrm{HCl}-\mathrm{H}_{2} \mathrm{O}(1: 1,24 \mathrm{~mL})$ and then was diluted with $40 \mathrm{~mL}$ of $\mathrm{H}_{2} \mathrm{O}$. After 1 $\mathrm{h}$ at room temperature, the precipitate was filtered off and recrystallized from $\mathrm{AcOH}$. Yield $1.39 \mathrm{~g}, 85 \%$.

Method B. A solution of 3-(1,3benzothiazol-2-yl)-8-dimethylaminomethyl7-hydroxy-2H-2-chromenone 3 (0.53 g, 1.5 mmol) and hexamethylenetetramine $0.42 \mathrm{~g}$ (3 mmol) in $5 \mathrm{~mL}$ of acetic acid was refluxed for $1 \mathrm{~h}$. The hot solution was poured into a hot mixture of $\mathrm{HCl}-\mathrm{H}_{2} \mathrm{O}(1: 1$, $3 \mathrm{~mL}$ ) and then was diluted with $15 \mathrm{~mL}$ of $\mathrm{H}_{2} \mathrm{O}$. After $1 \mathrm{~h}$ at room temperature, the precipitate was filtered off and recrystallized from $\mathrm{AcOH}$. Yield $0.35 \mathrm{~g}, 73 \%$. Orange solid, $\mathrm{C}_{17} \mathrm{H}_{9} \mathrm{NO}_{4} \mathrm{~S}, \mathrm{mp} 234-235^{\circ} \mathrm{C}(\mathrm{AcOH})$. ${ }^{1} \mathrm{H}$ NMR spectrum $\left(400 \mathrm{MHz}, \mathrm{DMSO}-d_{6^{-}}\right.$ $\left.\mathrm{CCl}_{4}\right), \delta, \operatorname{ppm}(J, \mathrm{~Hz}): 7.02(1 \mathrm{H}, \mathrm{d}, J=8.8$, H-6), 7.36 (1H, t, $\left.J=7.6, \mathrm{H}^{-6}{ }^{\prime}\right), 7.46(1 \mathrm{H}, \mathrm{t}$, $\left.J=7.6, \mathrm{H}-5^{\prime}\right), 7.94$ (1H, d, J=7.6, H-4'), 7.98 $\left(1 \mathrm{H}, \mathrm{d}, J=7.6, \mathrm{H}^{-} 7^{\prime}\right), 8.08$ (1H, d, $J=8.8, \mathrm{H}-$ 5), 9.09 (1H, s, H-4), 10.48 (1H, s, CHO), 
$12.19(1 \mathrm{H}, \mathrm{s}, \mathrm{OH}) . \mathrm{MS}(\mathrm{m} / z, \mathrm{CI}): 324$ $[\mathrm{MH}]^{+}$.

3-(1,3-Benzothiazol-2-yl)-8-(4nitrobenzoyl)-2H-furo[2,3-h]chromen-2-one 7. $\mathrm{K}_{2} \mathrm{CO}_{3}(0.14 \mathrm{~g}, 1 \mathrm{mmol})$ was added to a solution of 3-(1,3-benzothiazol-2-yl)-7hydroxy-2-oxo-2H-8-chromenecarbaldehyde 6 (0.32 g, $1 \mathrm{mmol})$ and 4-nitrophenacyl bromide $(0.24 \mathrm{~g}, 1 \mathrm{mmol})$ in $2 \mathrm{~mL}$ of DMF. The reaction mixture was stirred under heating $\left(100^{\circ} \mathrm{C}\right)$ for $5 \mathrm{~h}$, then cooled, diluted with $\mathrm{H}_{2} \mathrm{O}(20 \mathrm{~mL})$, neutralized with $\mathrm{HCl}$. The resulting residue was filtered off and recrystallized from dioxane. Yield $0.15 \mathrm{~g}$, $32 \%$. Pale yellow solid, $\mathrm{C}_{25} \mathrm{H}_{12} \mathrm{~N}_{2} \mathrm{O}_{6} \mathrm{~S}, \mathrm{mp}>$ $300^{\circ} \mathrm{C}$ (dioxane). ${ }^{1} \mathrm{H}$ NMR spectrum (400 $\left.\mathrm{MHz}, \mathrm{DMSO}-d_{6}\right), \delta, \mathrm{ppm}(J, \mathrm{~Hz}): 7.45(1 \mathrm{H}$, t, $\left.J=8.0, \mathrm{H}-6^{\prime}\right), 7.55\left(1 \mathrm{H}, \mathrm{t}, J=8.0, \mathrm{H}-5^{\prime}\right)$, $7.90(1 \mathrm{H}, \mathrm{d}, J=8.0, \mathrm{H}-5), 8.05(1 \mathrm{H}, \mathrm{d}, J=$
8.0, H-6), 8.15 (5H, m, H-4', $\left.7^{\prime}, 9,2^{\prime \prime}, 6^{\prime \prime}\right)$, $8.42\left(2 \mathrm{H}, \mathrm{d}, J=7.6, \mathrm{H}-3^{\prime \prime}, 5^{\prime \prime}\right), 9.38(1 \mathrm{H}, \mathrm{s}$, H-4). MS (m/z, CI): $469[\mathrm{MH}]^{+}$.

\section{Results and discussion}

As part of our ongoing research into the reactivity of 7-hydroxy-3-(benzothiazol2-yl)coumarin, in this work we explored the construction of hetarenocoumarins based on 7-hydroxy-3-(benzothiazol-2-yl)coumarin and its functional derivatives.

The Knoevenagel methodology [18] was utilized to synthesize 7-hydroxy-3(benzothiazol-2-yl)coumarin $\mathbf{1}$, but the hydrolysis of the reaction mixture was performed in refluxing acetic acid (Scheme 1).

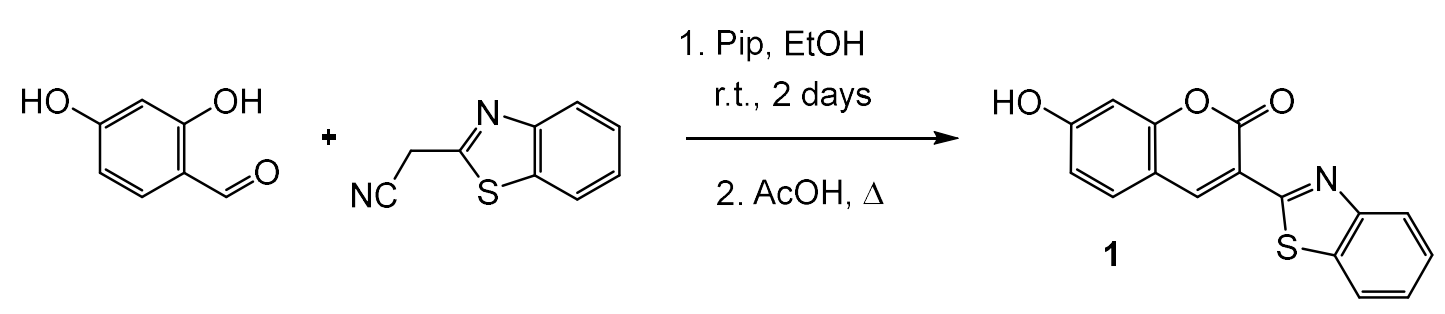

Scheme 1. The synthesis of 7-hydroxy-3-(benzothiazol-2-yl)coumarin

It is known that aminomethylation of 7-hydroxycoumarin $\mathbf{1}$ with bisdimethylaminomethane in dioxane produces 8-dimethylaminomethyl derivative 2 [18].
Aminomethylation of 7-hydroxycoumarin 1 under classical conditions using benzylamines and an excess of $37 \%$ formalin in dioxane led to the annelation of the dihydrooxazine cycle to the coumarin ring and the formation of 3-(1,3- 
benzothiazol-2-yl)-9-benzyl-9,10-dihydro$2 H, 8 H$-chromeno[8,7-e][1,3]oxazin-2-ones 3a-c (Scheme 2). It should be noted that the addition of $\mathrm{HCl}$ to the refluxing solution of 3a-c in dioxane resulted in the opening of the oxazine cycle and the formation of Mannich bases hydrochlorides 4a-c (Scheme 2).

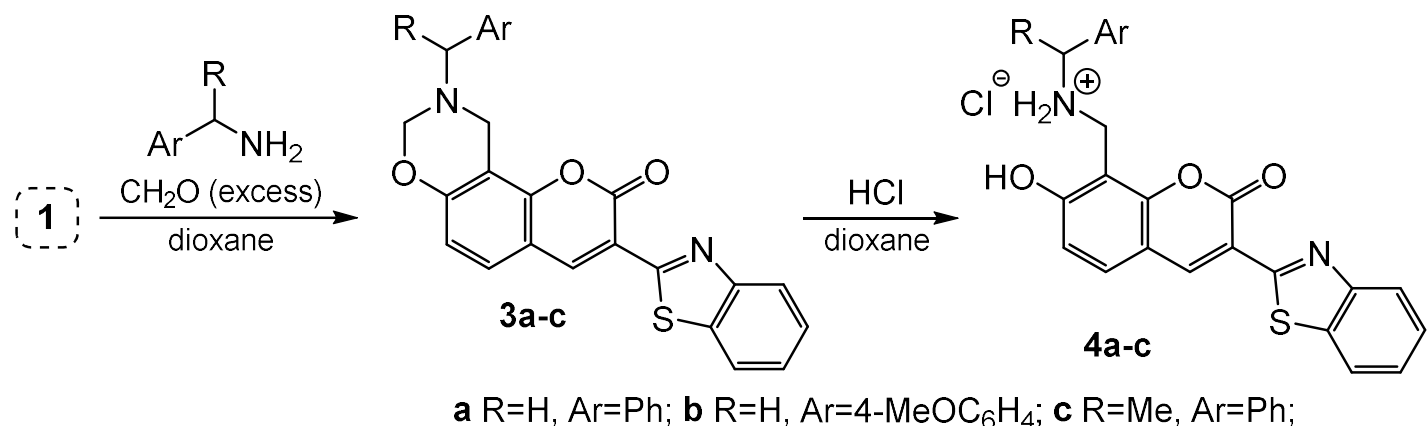

Scheme 2. The synthesis of 3-(1,3-benzothiazol-2-yl)-9-R-9,10-dihydro-2H,8H-chromeno[8,7-e][1,3] oxazin-2-ones 3a-c and 3-(1,3-benzothiazol-2-yl)-8-R-aminomethyl-7-hydroxy-2H-2-chromenons' hydrochlorides 4a-c

The corresponding Mannich bases 4a-c were obtained via interaction of 8dimethylaminomethyl derivative $\mathbf{2}$ with<smiles>CN(C)Cc1c(O)ccc2cc(-c3nc4ccccc4s3)c(=O)oc12</smiles>

$$
\text { (2) }
$$

benzylamines in dioxane at reflux for 2 hours (Scheme 3).

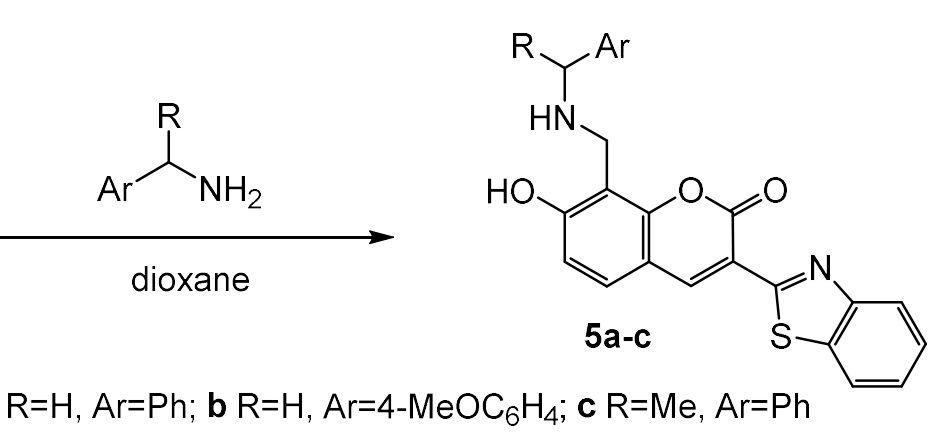

Scheme 3. The synthesis of 3-(1,3-benzothiazol-2-yl)-8-R-aminomethyl-7-hydroxy-2H-2-chromenons 5a-c

The ${ }^{1} \mathrm{H} \quad \mathrm{NMR} \quad$ spectra of chromeno[8,7-e][1,3]oxazin-2-ones $\mathbf{3 a , b}$ revealed the presence of three two-proton singlets at 3.81-3.90 ppm $\left(\mathrm{ArCH}_{2}\right)$, 4.13-
4.16 ppm (10- $\left.\mathrm{CH}_{2}\right)$, and 4.97-4.98 ppm (8$\mathrm{CH}_{2}$ ) assigned to the benzyl group and two methylene groups of the dihydrooxazine ring correspondingly, while the ${ }^{1} \mathrm{H}$ NMR spectra 
of $\mathbf{4 a , b}$ and $\mathbf{5 a , b}$ showed two two-proton singlets at 4.17-4.24 ppm $\left(8-\mathrm{CH}_{2}\right)$ and 3.91$4.20 \mathrm{ppm}\left(\mathrm{CH}_{2} \mathrm{Ar}\right)$. The signals of dihydrooxazine ring protons in the ${ }^{1} \mathrm{H}$ NMR spectrum of 9-(1-phenylethyl) derivative 3c are not equivalent due to their proximity to the asymmetric center.

Taking into account that $o$-hydroxyformyl coumarins are convenient building blocks for the synthesis of condensed coumarins $[25,26]$, we targeted 3-(1,3benzothiazol-2-yl-7-hydroxy-2-oxo- $2 H-8$ - chromenecarbaldehyde $\mathbf{6}$ as an appropriate substrate for the synthesis of hetarenocoumarins. Previously, 8-formyl derivative 6 was synthesized from 7hydroxy-3-(benzothiazol-2-yl)coumarin 1 by its interaction with hexamethylenetetramine in trifluoroacetic acid via the Duff reaction [23, 24]. Replacing trifluoroacetic acid with acetic acid as a solvent in this reaction allowed us to obtain product $\mathbf{6}$ in good yield and reduce the above protocol's cost (Scheme 4).

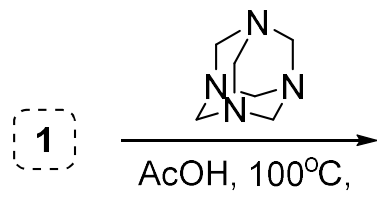

$6 \mathrm{~h}$<smiles>O=Cc1c(O)ccc2cc(-c3nc4ccccc4s3)c(=O)oc12</smiles>

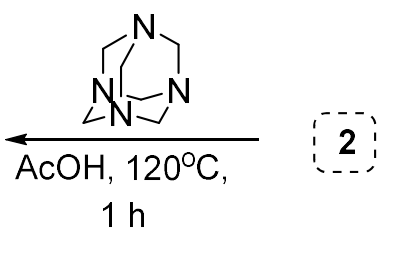

Scheme 4. The syntheses of 3-(1,3-benzothiazol-2-yl-7-hydroxy-2 oxo-2H-8-chromenecarbaldehyde (6)

$$
\text { 3-(1,3-Benzothiazol-2-yl)-8- }
$$

dimethylamino-methyl-7-hydroxy-2H-2-

chromenone 2 can also be a starting material in the synthesis of 8-formylcoumarin 6 via the Duff reaction. Treatment of $\mathbf{2}$ with hexamethylenetetramine in acetic acid at reflux for $1 \mathrm{~h}$ followed by hydrolysis with $\mathrm{HCl}$ gave 5 in $73 \%$ yield.

\section{7-Hydroxy-8-formylcoumarin $\quad 6$} was introduced into a reaction with 4-nitrophenacyl bromide upon heating in dimethylformamide at $100^{\circ} \mathrm{C}$ in the presence of $\mathrm{K}_{2} \mathrm{CO}_{3}$. Ring closure proceeded via alkylation of the hydroxyl group followed by the condensation of active methylene and carbonyl groups, forming the furan fragment and leading to the formation of 3-(1,3-benzothiazol-2-yl)-8-(4-nitrobenzoyl)-2H-furo[2,3- $h]$ chromen-2-one 7 (Scheme 5). The presence of a singlet at 8.19 ppm for the H-3 proton in the ${ }^{1} \mathrm{H}$ NMR spectrum of this compound is consistent with the formation of a furochromene system. 

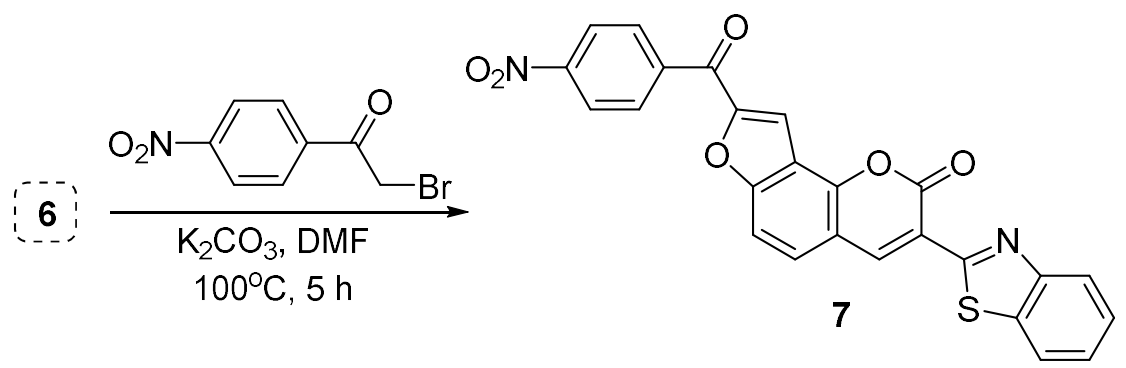

Scheme 5. The syntheses of furo[2,3-h] coumarin 7

\section{Conclusions}

In conclusion, we have performed the synthesis of angular hetarenocoumarines, namely chromeno[8,7-e][1,3]oxazin-2-ones based on 7-hydroxy-3-(benzothiazol-2yl)coumarin via aminomethylation under classical Mannich reaction conditions using an excess of formalin. The furo[2,3$h$ ]chromen-2-one system was formed starting from the 8-formyl derivative of 7hydroxy-3-(benzothiazol-2-yl)coumarin under the Duff reaction conditions with 4nitrophenacyl bromide. The proposed approaches are simple and effective and will contribute to further unlocking the potential of coumarins.

\section{Acknowledgement}

This work has been supported by Ministry of Education and Science of Ukraine: Grant of the Ministry of Education and Science of Ukraine for perspective development of a scientific direction "Mathematical sciences and natural sciences" at Taras Shevchenko National University of Kyiv.

\section{References}

[1] Sarker SD, Nahar L. Progress in the Chemistry of Naturally Occurring Coumarins. In: Kinghorn A., Falk H., Gibbons S., Kobayashi J. (eds) Progress in the Chemistry of Organic Natural Products. 2017;106:241304.

[2] Gouda MA, Salem MA, Helal MH. A Review on Synthesis and Pharmacological Activity of Coumarins and Their Analogs. Curr. Bioactive Compd. 2020;16 (6):818-836.

[3] Chao RY, Ding MF, Chen JY, Lee CC, Lin ST. Preparation and Characterization of Substituted 3Benzothiazol-2-ylcoumarins J. Chin. Chem. Soc. 2010;57(2):213-221.

[4] Jin X, Wu X, Xie P, Liu S, Wu J, Wang T, Zhou $H$, Leng $X$, Chen W. Reaction-based fluorescent probes for rapid detection of hydrogen sulfide: In vivo. Analytical Methods. 2018;10(33):4079-4084.

[5] Lin W, Long L, Tan W. A highly sensitive fluorescent probe for detection of benzenethiols in environmental samples and living cells. Chem. Comm. 2010;46(9):1503-1505.

[6] Zhang Q, Ding S, Zhai Q, Feng G. Highly sensitive and selective detection of biothiols by a new 
low dose colorimetric and fluorescent probe. RSC Advances. 2015;5(77):62325-62330.

[7] Zhang H, Li M, Feng W, Feng G. Rapid and selective detection of selenocysteine with a known readily available colorimetric and fluorescent turn-on probe. Dyes and Pigments. 2017;149:475-480.

[8] Tong KY, Zhao J, Tse CW, Wan PK, Rong J, AuYeung HY. Selective catecholamine detection in living cells by a copper-mediated oxidative bond cleavage. Chem. Sci. 2019;10(37):8519-8526.

[9] Tan W, Leng T, Lai G, Li Z, Wang K, Shen Y, Wang C. A novel coumarin-based fluorescence enhancement and colorimetric probe for $\mathrm{Cu}^{2+}$ via selective hydrolysis reaction. J. Photochemistry and Photobiology A: Chemistry. 2016;324:81-86.

[10] Wang K, Zhao C, Guo S, Lu Y, Shen Y, Wang C. A coumarin-based near-infrared fluorescent probe with a large stokes shift for the sequential recognition of $\mathrm{Ni}^{2+}$ and $\mathrm{CN}^{-}$: Performance research and quantum calculation. J. Photochemistry and Photobiology A: Chemistry. 2019;382:111943.

[11] Guo SH, Guo ZQ, Wang CY, Shen Y, Zhu WH. An ultrasensitive fluorescent probe for hydrazine detection and its application in water samples and living cells. Tetrahedron. 2019;75(18):2642-2646.

[12] Yu ZH, Chung CY, Tang FK, Brewer TF, AuYeung HY. A modular trigger for the development of selective superoxide probes. Chem. Comm. 2017;53 (72):10042-10045.

[13] Wang K, Lai G, Li Z, Liu M, Shen Y, Wang C. A novel colorimetric and fluorescent probe for the highly selective and sensitive detection of palladium based on $\operatorname{Pd}(0) \quad$ mediated reaction. Tetrahedron. 2015;71(41):7874-7878.

[14] Li C, Wang S, Huang Y, Wen Q, Wang L, Kan Y. Photoluminescence properties of a novel cyclometalated iridium(III) complex with coumarinboronate and its recognition of hydrogen peroxide. Dalton Transactions. 2014;43(14):5595-5602.

[15] Azim SA, Al-Hazmy SM, Ebeid EM, El-Daly SA. A new coumarin laser dye 3-(benzothiazol-2-yl)-7hydroxycoumarin. Optics and Laser Technology. $2005 ; 37(3): 245-249$.

[16] Makowska A, Wolf L, Saczewski F, Bednarski PJ, Kornicka A. Synthesis and cytotoxic evaluation of benzoxazole/benzothiazole-2-imino-coumarin hybrids and their coumarin analogues as potential anticancer agents. Pharmazie. 2019;74: 648-657.

[17] Wang C, Xu F, Niu Y, Wu Y, Sun Y, Peng Y, Liang L, Xu P. Synthesis and biological evaluations of 3-benzothiazol-2-yl coumarin derivatives as MEK1 inhibitors. Letters in drug design and discovery. 2013;10(8):727-732.

[18] Khilya OV, Frasinyuk MS, Turov AV, Khilya VP. Chemistry of 3-hetarylcoumarins. 1. 3-(2benzazolyl)-coumarins. Chem. Heterocycl. Compd. 2001;37(8):1029-1037.

[19] Syzova ZA, Karasyov AA, Lukatskaya LL, Doroshenko AO. Acid-base and spectral properties of 3-(benzothiazolyl-2)cumarins and their imino analogs. Kharkov University Bulletin. Chemical Series. 2016;26(49):26-37.

[20] Wolfbeis OS, Koller E, Hochmuth P. The Unusually Strong Effect of a 4-Cyano Group upon Electronic Spectra and Dissociation Constants of 3Substituted 7-Hydroxycoumarin. Bull. Chem. Soc. Jpn. $1985 ; 58(2): 731-734$.

[21] Khoobi M, Ramazani A, Foroumadi AR., Hamadi H, Hojjati Z, Shafiee A. Efficient Microwave-Assisted Synthesis of 3-Benzothiazolo and 3-Benzothiazolino Coumarin Derivatives Catalyzed by Heteropoly Acids. J. Iran. Chem. Soc. 2011;8(4):1036-1042. 
[22] Frasinyuk MS, Turov AV, Vinogradova VI., Khilya VP. Aminomethylation of cytisine by 3-hetaryl7-hydroxycoumarins. Chem. Nat. Compd. 2007;43(2):176-180.

[23] Roubinet B, Renard P-Y, Romieu A. New insights into the water-solubilization of thiol-sensitive fluorogenic probes based on long-wavelength 7hydroxycoumarin scaffolds. Dyes and Pigments. 2014;110:270-284.

[24] Li J, Li X, Jia J, Chen X, Lv Y, Guo Y, Li J. A ratiometric near-infrared fluorescence strategy based on spiropyran in situ switching for tracking dynamic changes of live-cell lysosomal pH. Dyes and Pigments. 2019;166:433-442.

[25] Shokol TV, Moskvina VS, Glebov EK, Khilya VP. Neoflavonoid Angelicin Derivatives. Chem. Nat. Compd. 2019;55(4):716-718.

[26] Moskvina VS, Khilya VP. Synthesis of pyrano[2,3-f]chromen-2,8-diones and pyrano[3,2$g$ ]chromen-2,8-diones based on $o$ hydroxyformyl(acyl)-neoflavonoids. Chem. Nat. Compd. 2008;44(1):16-23. 